\title{
European Higher Education in the Context of Brexit
}

\author{
Sacha Garben*
}

It seems that for a long time, in European higher education at least, the UK could have its cake and eat it too. One of the four original architects of the European Higher Education Area (E HEA; which is the culmination of the 1998 intergovernmental Sorbonne Declaration and ensuing Bologna Process), the UK has successfully exported the main features of its higher education model to the other EU Member States and beyond, without having to concede any powers to the EU level in that regard, as the Bologna Process remains formally outside the EU's institutional and legal framework. ${ }^{1}$ With the participating countries mainly converging to the UK system, embracing its Bachelor-MasterDoctorate degree structure as well as more implicitly its overall liberal, marketdriven approach to higher education, the UK reaped all the benefits of an enlarged higher education "market" on which its higher education institutions could successfully compete, at minimal administrative, political or other cost.

Furthermore, in EU higher education law and policy, the UK has occupied an equally advantageous position. In the specific context of the EU's European Research Area (ERA), the UK's higher education sector has been very successful in obtaining EU research funding. This could potentially be linked to the fact that, as a major net importer of mobile EU students, researchers and academics - who flocked to the UK as a result of a combination of inter alia linguistics, the reputation of its universities and international outlook, as well

* Professor of EU Law at the College of Europe, Bruges, and on leave from the European Commission. The views expressed in this chapter are entirely personal and in no way reflect the official position of the European Commission. The author wishes to thank the participants of the workshop on "EU Citizenship in Times of Brexit" at the University of Leuven on 30 March 2018 for their feedback on a previous draft of the paper, and in particular Christa Tobler for very useful comments.

1 See for a general discussion Garben, S. (2014). EU Higher Education Law - The Bologna Process and Harmonization by Stealth. Alphen aan de Rijn: Kluwer Law International. 
as its open labour market - the UK has profited from a major brain-gain. At the same time, because of the UK's liberal, fee-paying model, this imported wealth and talent has come at a very low cost. This is because the EU's case law on student mobility and diploma recognition has worked mainly to the benefit of the UK model, where it requires equal treatment as regards tuition fees but not maintenance grants. Although the Court developed students' mobility rights already before the introduction of EU citizenship in the Treaty of Maastricht, it has since then relied on this 'fundamental status' of Member State nationals to further strengthen its protective approach. ${ }^{2}$ The (ideal-type) mobile student, with its youthful ambition and potential to develop a pan-European career, life and identify, is in many ways the embodiment of both the aspirational and instrumental aspects of EU citizenship.

What will be the impact of Brexit? While we shall leave concrete predictions to futurologists, this paper will reflect on the underlying dynamics in this area, from a legal and political point of view, and will thereby indicate the relevant "stakes" and "pressure points" which are likely to come to the fore in the Brexit negotiations in respect of the area of higher education. It will be argued that while the EHEA is independent from EU membership, and the UK will thus presumably remain party to it post-Brexit, a country's successful performance within the EHEA is deeply connected to (and dependent on) the EU's "hard" free movement rights deriving from EU citizenship and the internal market. In addition, in terms of the ERA, it is clear that UK universities stand a lot to lose if Brexit would bar them from obtaining EU research funding, making this an important bargaining chip for the EU, both within the negotiations and potentially as leverage for the UK's compliance with its obligations under any future relationship. As such, the UK's current strength in higher education is one of its weak spots in the Brexit negotiations.

Part 2 of the paper will set out the general elements of European higher education law and policy, Part 3 will consider the current position of the UK in both this context, while part 4 will explore the possible implications of, and for, Brexit. Part v concludes.

Over the past two decades, a remarkable amount of Europeanization has occurred in higher education, an area that has traditionally been closely guarded

2 See Chapter 4 in Garben, S. (2014). EU Higher Education Law, cit. 
by EU Member States as one of the remaining bastions of national identity and autonomy. This Europeanization has taken place, and continues to develop, in two main forums. The most fundamental European influence on national higher education systems has come from the intergovernmental Bologna Process, which has resulted in the so-called European Higher Education Area (E HEA). The second source of Europeanization is the EU, which since the Maastricht Treaty possesses a direct competence in education in the form of (what is now, since the Lisbon Treaty) Article 165 TFEU.

\section{II.1 The Bologna Process and the EHEA}

The Bologna Process was initiated in 1998, when at an international forum organized in connection with the celebration of the $800^{\text {th }}$ anniversary of the Sorbonne University, the Ministers of education of France, Germany, Italy and the United Kingdom decided on a "Joint Declaration on harmonisation of the architecture of the European higher education system". It was open for the other Member States of the EU as well as for third countries to join. Belgium, Switzerland, Romania, Bulgaria and Denmark accepted and signed immediately. The Italian minister for education extended an invitation to fellow European ministers to a follow-up conference, taking place in Bologna the following year. ${ }^{3}$ On this occasion, in June of 1999, 29 European countries agreed on a declaration that would fundamentally change the future of their higher education systems. From this Bologna Declaration ensued the Bologna Process, which now includes 48 countries and the European Commission as "members".

The Process is an on-going platform for policy-exchange and policy-making in higher education, organized around regular (bi- or triannual) ministerial conferences, which assess the progress made in reference to the various previously established Bologna policy objectives and which add new aims and elements. The original deadline of the Process was the creation of a European Area of Higher Education by 2010, but the Process has continued despite the EHEA's official launch in March 2010 during the Budapest-Vienna Ministerial Conference. While the Process has significantly branched out in terms of scope and objectives over the years, at its heart is still the structural "harmonisation" 5

3 Hackl, E. (2001). Towards a European Area of Higher Education: Change and Convergence in European Higher Education. EUI Working Paper, no. 9, p. 21.

4 All EU Member States, as well as Albania, Andorra, Armenia, Azerbaijan, Belarus, Bosnia and Herzegovina, Georgia, Holy See, Iceland, Kazakhstan, Liechtenstein, Moldova, Montenegro, Norway, Russia, Switzerland, Macedonia, Serbia, Turkey and the Ukraine.

5 The Sorbonne Declaration, which is seen as the basis for the Bologna Declaration and Process, carries the term 'harmonisation' in its very title. However, in contrast with the Sorbonne 
of Europe's higher education systems, through the introduction of a common higher education system consisting in three (Bachelor-Master-Doctorate) cycles. The Bologna Declaration states that "access to the second cycle shall require successful completion of first cycle studies, lasting a minimum of three years. The degree awarded after the first cycle shall also be relevant to the European labour market as an appropriate level of qualification. The second cycle should lead to the master and/or doctorate degree as in many European countries". The main aim of this common system, and of the Bologna Process more generally, is to facilitate mobility in higher education and to improve the employability of graduates. The standardized degrees should be recognized in the participating countries, and to this end the Lisbon Recognition Convention of the Council of Europe ${ }^{6}$ is integrated into the Process by making its ratification an explicit Bologna "requirement". As an extension of the common three-tier structure and commitment to diploma recognition, the Process has increasingly focused on quality assurance mechanisms and standards, within which "employability" plays an important role.

It should be stressed that the Sorbonne and Bologna Declarations and the ensuing Process are not legally binding. Both participation in the Process and the 'implementation' of the Declarations and subsequent ministerial communiqués are entirely voluntary; they are "political artefacts" ${ }^{7}$ that may be re-

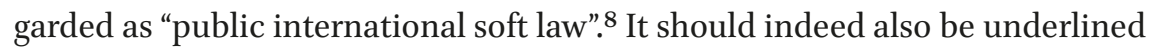
that the Bologna Process is formally separate from the EU and EU law. The European Commission is a "member" of Bologna alongside the participating counties, but the Process takes place outside the EU's institutional and legal framework. As we shall see in Section III, the UK has played an important

Declaration, the Bologna Declaration carefully avoids the use of the word. In fact, the question whether the envisaged Bologna project constituted 'harmonisation' is reported to have been a highly contentious issue that had to be resolved before the Declaration could be signed. There had already been discussion about the use of the term in the run-up to the conference. Most of the participating countries deemed the type of standardisation entailed by harmonisation to be undesirable in the field of higher education. Although the French minister Claude Allègre tried to convince his colleagues that 'harmonisation' as used in the text of the Declaration was not to mean 'standardisation' in its unwanted sense, the majority of participants preferred to stay on the safe side and leave out the term. See: Kirkwood-Tucker, T. (2004). Toward a European Model of Higher Education Processes, Problems, and Promises. European Education 36 (3), pp. 51-69.

61997 Convention on the Recognition of Qualifications concerning Higher Education in the European Region.

7 Amaral A., and Magalhaes, A. (2004). Epidemiology and the Bologna Saga. Higher Education 48 (1), pp. 79-100, 84 .

8 Hackl, E. (2001). Towards a European area of higher education, cit, p. 28. 
role in ensuring that the Bologna Process would remain an intergovernmental, voluntary project, keeping the EU on the side-lines. But also a number of other EU Member States were (initially) eager to exclude the EU, perhaps as 'retribution' for the EU's growing role in the area despite its initial lack of direct competence. ${ }^{9}$

I have argued elsewhere that the exclusion of the EU and the intergovernmental nature of the Bologna Process have led to a number of legitimacy problems, and that it would in fact have been better to adopt the Declaration as a binding measure within an EU context. ${ }^{10}$ In any event, the activities undertaken in the context of Bologna overlap to an important extent with EU policies and initiatives, and its objectives are closely connected to an EU corpus legis. The Commission is heavily involved by means of funding and steering, and characterizes its contribution to the Process as part of the Lisbon/Europe 2020 Strategy. ${ }^{11}$ The Bologna follow-up relies heavily on the EU presidency and the European Credit Transfer System (ECTS) has been transposed into the Bologna Process' Bachelor-Master system. Furthermore, since 2015, the EU offers a Student Loan Guarantee Facility, which provides partial guarantees to financial intermediaries in respect of loans granted to students undertaking a secondcycle degree, such as a Master's degree, which is neither their country of residence nor the country in which they obtained their qualification granting access to the Master's programme. ${ }^{12}$ Once fully implemented, ${ }^{13}$ this EU measure is of course an important support for the system and the goals of the Bologna Process. All of this makes the exact status of the Bologna Process obscure and means that in spite of the intentions of the (original) Bologna actors, the EHEA is deeply connected to the EU's institutional and legal framework, even if it remains formally separate from it.

9 For extensive discussion, see: Garben, S. (2014). EU Higher Education Law, cit.

10 Ibid; Garben, S. (2010). The Bologna Process: from a European law perspective. European Law Journal 16 (2), pp. 186-210. .

11 European Commission (2003). Realising the European Higher Education Area, Contribution of the European Commission to the Berlin Conference of European Higher Education Ministers on 18/19 Sept. 2003.

12 Regulation (EU) No 1288/2013 of the European Parliament and of the Council of 11 December 2013 establishing "Erasmus+": The Union programme for education, training, youth and sport and repealing Decisions No 1719/2006/EC, No 1720/2006/EC and No 1298/ 2008/EC, OJ L 347, 20.12.2013, p. 50-73.

13 Currently the scheme is being made available through banks and universities, with only limited coverage. See https:/ec.europa.eu/programmes/erasmus-plus/opportunities/ individuals/students/erasmus-plus-master-degree-loans_en. 
As was just indicated, the EU features a range of laws and policies in the area of higher education, and this was already the case at the time of the Bologna Declaration's genesis. This may be to the surprise of some, considering that the 1957 Rome Treaty did not confer any specific powers for the development of a common educational policy. This absence however did not deter the European Court of Justice to expand its influence and to help establish a "Community law of education",14 stating that "although educational and training policy is not as such included in the spheres which the Treaty has entrusted to the Community Institutions, it does not follow that the exercise of powers transferred to the Community is in some way limited if it is of such a nature as to affect the measures taken in the execution of a policy such as that of education and training". ${ }^{15}$ Moreover, there was not a complete lack of explicit competence in educational matters. Article $57 \mathrm{EEC}$ (now Article $53 \mathrm{TFEU}$ ) granted legislative powers for the mutual recognition of diplomas. Furthermore, the EEC Treaty also provided for competence in vocational training. It is in fact on this provision that the EU's initial education law was developed. In its consequential Gravier judgment, where the Court held that Member states cannot charge higher enrolment fees to non-national EU students, the Court interpreted vocational training to include an element of "general education". ${ }^{16}$ Shortly afterwards, the Commission presented the Erasmus programme for student exchange ${ }^{17}$ solely under Article $128 \mathrm{EC}$ (now Article 166 TFEU on vocational training), ${ }_{18}$ and in a subsequent case, the Court largely upheld the Commission's

\footnotetext{
14 De Witte, B., ed.(1989). European Community Law of Education. Baden-Baden: Nomos.

15 Court of Justice, judgment of 3 July 1974, case 9/74, Donato Casagrande v. Landeshauptstadt München.

16 Court of Justice, judgment of 13 February 1985, case 293/83, Gravier. Further developed in Court of Justice, judgment of 2 February 1988, case 24/86, Blaizot v. University of Liege clarifying that this could also include university education whenever it prepares students for an occupation.
}

17 European Commission, Proposal for a Council Decision adopting ERASMUS, сом (1985) 756. Erasmus establishes a European University Network, encouraging universities by means of financial incentives to set up student and teacher exchange agreements. It gives out grants to the participating students; covering the cost of linguistic preparation for the studies abroad, travel expenditure and compensation for the higher cost of living in the host state. Erasmus is very much a success story, in terms of numbers, outcomes and perception. See European Commission (2007). Erasmus: Success Stories: Europe Creates Opportunities. Luxembourg: Office for Official Publications of the European Communities.

18 Pépin, L. (2007). The history of EU cooperation in the field of education and training: How lifelong learning became a strategic objective. European Journal of Education 42 (1), pp. 121-132, 124. Lenaerts, K. (1989). Erasmus: Legal basis and implementation. In: De 
wide interpretation of this provision so as to apply to university education. ${ }^{19}$ Even if this discussion has been long superseded since the introduction of a specific legal basis for education in the Maastricht Treaty (the most recent incarnation of the programme, ERASMUS,$+{ }^{20}$ is based on both Article 165 and 166 TFEU), this story remains interesting as it shows the dynamics behind the evolution of this area.

The Court's case law on student mobility has developed since the seminal Gravier judgment, making clear that EU citizens have the right to higher education in other EU Member States on the same terms as nationals, which does not only require equal treatment as regards access conditions and tuition fees, but in principle also as regards maintenance grants. In the Bidar case, the Court included student maintenance for the purposes of the application of the prohibition of discrimination as a matter of principle. ${ }^{21}$ Remarkably, the Court used the Citizenship Directive 2004/38, ${ }^{22}$ which provides in its recital 21 that it should be left to the host Member State to decide whether it will grant maintenance assistance for studies, and in Article 24(2) that the host Member States "shall not be obliged to [...] grant maintenance aid for studies" prior to acquisition of the right of permanent residence, as an argument that the grant of such aid actually falls within the scope of the Treaty. ${ }^{23}$ Contrary

Witte, ed., European Community Law of Education, cit, p. 116; Shaw, J. (1992). Education and the law in the European Community. Journal of Law \& Education 21 (3), pp. 415-442, 420.

19 Court of Justice, judgment of 30 May 1989, case 242/87, Commission v. Council (Erasmus).

20 Regulation (EU) No 1288/2013 of the European Parliament and of the Council of 11 December 2013 establishing "Erasmus+": the Union programme for education, training, youth and sport and repealing Decisions No 1719/2006/EC, No 1720/2006/EC and No 1298/ 2008/EC, OJ L 347 , 20.12.2013, p. 50-73.

21 Court of Justice, judgment of 15 March 2005, case C-209/o3, The Queen, on the application of Dany Bidar v. London Borough of Ealing and Secretary of State for Education and Skills.

22 Directive 2004/38/EC of the European Parliament and of the Council of 29 April 2004 on the right of citizens of the Union and their family members to move and reside freely within the territory of the Member States amending Regulation (EEC) No 1612/68 and repealing Directives 64/221/EEC, 68/36o/EEC, 72/194/EEC, 73/148/EEC, 75/34/EEC, 75/35/ EEC, 9o/364/EEC, 9o/365/EEC and 93/96/EEC, OJ L 158, 30.4.2004, p. 77-123.

23 The Court stated: "That development of Community law is confirmed by Article 24 of Directive 2004/38, which states in paragraph 1 that all Union citizens residing in the territory of another Member State on the basis of that directive are to enjoy equal treatment 'within the scope of the Treaty'. In that the Community legislature, in paragraph 2 of that article, defined the content of paragraph 1 in more detail, by providing that a Member State may in the case of persons other than workers, self-employed persons, persons who retain such status and members of their families restrict the grant of maintenance aid in the form of grants or loans in respect of students who have not acquired a right of permanent residence, it took the view that the grant of such aid is a matter which, in 
to the expectations raised by Bidar that students may qualify for maintenance aid before obtaining the right of permanent residence after 5 years of legal residence, in the Förster case the Court allowed for an extensive derogation of this principle, so that under the current state of affairs only those students of foreign EU nationality are eligible that have spent 5 years in the host State before applying. ${ }^{24}$ As regards the exportability of maintenance grants and loans, the Court held in Morgan and Bucher that "where a Member State provides for a system of education or training grants which enables students to receive such grants if they pursue studies in another Member State, it must ensure that the detailed rules for the award of those grants do not create an unjustified restriction of the right to move and reside within the territory of the Member States". 25

This distinction between access conditions, comprising tuition fees, on the one hand, for which full equal treatment of mobile students is required, and on the other hand maintenance support for which equal treatment will only apply in exceptional cases, has an asymmetrical effect on Member States' higher education systems. Where a Member States subsidizes and organizes higher education through free or low-tuition access, EU law requires them to extend this to mobile EU students. Where, on the other hand, it subsidizes and organizes higher education through maintenance grants and loans, it does not have to do so. This works to the disadvantage of Member States with a social model of higher education, as "EU law requires Member States which choose to devote significant public resources to maintaining a high quality further education system for the benefit of their own populations to subsidize, through the principle of equal access, in addition potentially large numbers of foreign students" 26 while more Member States with a more 'liberal' model with high tuition fees and support through maintenance grants or loans have to pay significantly less to mobile students in comparison.

In addition to the provision on vocational training discussed above, the Rome Treaty featured another competence related to education: Article 53

accordance with Article 24(1), now falls within the scope of the Treaty". See paragraph 43 of the judgment.

24 Court of Justice, judgment of 18 November 2008, case C-158/07, Jacqueline Förster v. Hoofddirectie van de Informatie Beheer Groep.

25 Court of Justice, judgment of 23 October 2007, joined cases C-11/o6 and C-12/o6, Rhiannon Morgan v. Bezirksregierung Köln (C-11/o6) and Iris Bucher v. Landrat des Kreises Düren (C12/06), para. 28.

26 Dougan, M. (2005). Fees, Grants, Loans and Dole Cheques: Who Covers the Costs of Migrant Education within the EU?. Common Market Law Review 42 (4), pp. 943-986. 
TFEU on recognition of diplomas. Professional diploma recognition deals with the rules of Member States that make access to or pursuit of a regulated profession in their territory contingent on possession of professional qualifications. ${ }^{27}$ Article $53 \mathrm{TFEU}$ provides an explicit legal basis for legislative action, approaching the issue from an internal market logic. Considering that currently around 800 professions are regulated by one or more Member States, the establishment of a common employment market would be fundamentally impaired if Member States could carve out these professions by applying their different statutory regimes. This has allowed the EU to adopt a range of legal measures. The numerous directives on co-ordination of training and recognition of qualifications have had a direct impact on content of courses. ${ }^{28}$ For instance, Directive $78 / 687$ caused the entire dentistry curriculum of Italian universities to be recreated..$^{29}$ The most important current measure is umbrella Directive 2005/36/EC. ${ }^{30}$ It consolidated almost all the previous legislation, except for the specific directives on the provision of services and establishment of lawyers. ${ }^{31}$ The umbrella directive does not substantially impact the higher education systems of the Member States in a direct way. It does not propose the harmonization of new professions, but simply applies a mutual recognition approach to the non-coordinated professions. Still, the mechanism of mutual recognition might have an effect on the national higher education systems, as it could put pressure on the systems that are less 'efficient'.

In contrast to professional recognition, academic recognition is said to be concerned with the academic status of obtained degrees. Academic recognition is often regarded to lie outside the scope of formal EU powers. Although it could be argued that this distinction is unfounded, ${ }^{32}$ no EU legislation

27 Schneider, H. (1995). Die Anerkennung von Diplomen in der Europäischen Gemeinschaft. Antwerp: Maklu.

28 Lonbay, J. (1989). Education and the law: The Community Context. European Law Review 14 (6), pp. $363-387,368$.

29 Zilioli, C. (1989). The Recognition of Diplomas and its Impact on Educational Policies. In; B. de Witte, ed., European Community Law of Education, cit., 51.

30 Directive 2005/36/EC of the European Parliament and of the Council of 7 September 2005 on the recognition of professional qualifications, OJ L 255, 30.9.2005, p. 22-142.

31 Council Directive 77/249/EEC of 22 March 1977 to facilitate the effective exercise by lawyers of freedom to provide services, $O J L 78,26.3 .1977$, p. 17-18 and Directive 98/5/EC of the European Parliament and of the Council of 16 February 1998 to facilitate practice of the profession of lawyer on a permanent basis in a Member State other than that in which the qualification was obtained, $O J L 77,14 \cdot 3.1998$, p. 36-43.

32 Garben, S. (2011). On Recognition of Qualifications for Academic and Professional Purposes. Tilburg Law Review 16 (2)2011, pp. 127-156. 
concerning the academic recognition of diplomas has been adopted. That is not to say that no European integration has taken place in this area. Firstly, the EU has adopted a number of supporting measures to facilitate academic recognition, such as the European Credit Transfer System for higher education (ECTS) ${ }^{33}$ and for vocational training (ECVET), ${ }^{34}$ Europass, ${ }^{35}$ the European Qualifications Framework ${ }^{36}$ and the Diploma Supplement. ${ }^{37}$ Moreover, the case law of the Court has played an important role also here, as it has held that the refusal to recognize academic diplomas or titles from other Member States can constitute a restriction of the fundamental freedoms. ${ }^{38}$ Beyond the mobility of students and diploma holders, EU law features important mobility rights for other education actors. Teachers qualify as "workers" and can therefore rely on all the rights and benefits connected to Article 45 TFEU. ${ }^{39}$ Furthermore, the activities of private education institutions qualify as "services" under Article $5^{6}$ TFEU. ${ }^{40}$ Similarly, private education institutions have the right to free establishment across the EU. Member States may therefore in principle not restrict privately funded higher education institutions from offering education

33 ECTS was developed by the Commission in the context of ERASMUS to enable students to take the credits obtained during their period of study abroad and use them within their home curriculum.

34 Recommendation of the European Parliament and of the Council of 18 June 2009 on the establishment of a European Credit system for Vocational Education and Training (ECVET), OJ $C_{155}, 8.7 .2009$, p. 11-18.

35 Decision (EU) 2018/646 of the European Parliament and of the Council of 18 April 2018 on a common framework for the provision of better services for skills and qualifications (Europass).

36 Recommendation of the European Parliament and of the Council of 23 April 2008 on the establishment of the European Qualifications Framework for lifelong learning, OJ C 111, 6.5.2008, p. 1-7. The EQF constitutes a European reference framework, consisting of 8 levels, based on "learning outcomes".

37 The Diploma Supplement is a European administrative annex to diplomas, which has been elaborated jointly by a working group of the European Commission, Council of Europe and UNESCO.

38 Court of Justice, judgment of 31 March 1993, case C-19/92, Dieter Kraus v. Land BadenWürttemberg. The non-recognition on equal terms of secondary school qualifications was considered a restriction of Arts. 18 and 21 TFEU on equal treatment of EU citizens, in Court of Justice, Judgments of 1 July 2004, 7 July 2005 and 13 April 2010 in cases C-65/o3, Commission v. Belgium, C-147/o3, Commission of the European Communities v. Republic of Austria, ECLI:EU:C:2005:427 and Case C-73/o8, Nicolas Bressol and Others, Céline Chaverot and Others v. Gouvernement de la Communauté française.

39 Court of Justice, judgment of 28 November 1989 , case 379/87, Anita Groener v. Minister for Education and the City of Dublin Vocational Educational Committee.

40 Court of Justice, judgment of 11 September 2007, case C-76/05, Herbert Schwarz, Marga Gootjes-Schwarz v. Finanzamt Bergisch Gladbach. 
programmes and degrees in other Member States, and the diplomas they issue should in principle be recognized by that host Member State. ${ }^{41}$

Further relevant EU measures include the Student Residence Directives. Directive $93 / 96^{42}$ granted students the right of residence in the Member State of study, but under the conditions of sufficient health insurance and sufficient resources to avoid becoming a burden on the host State's social assistance schemes. This Directive was repealed by Directive $2004 / 38^{43}$ on the right of citizens to move and reside freely within EU territory. The Directive constitutes a consolidation and clarification of all the legislation on the right of entry and residence for Union citizens. As discussed above, it indicates specifically that host Member States are not required, prior to the acquisition of the permanent right of residence, to grant maintenance aid for studies, including for vocational training, in the form of grants or loans. Directive 2004/114 in turn concerns students from third countries. The rationale behind the Directive is to "promote Europe as a whole as a world centre of excellence for studies and vocational training" by promoting the mobility of third-country nationals to the EU for the purpose of studies. ${ }^{44}$ The Directive distinguishes four categories of third-country nationals, namely students, school pupils, unpaid trainees and volunteers. The conditions for entry of students and pupils are that they have a valid travel document and, if minors, come with parental authorization, that they have sickness insurance and sufficient resources to cover their stay and that they have been accepted by a higher educational establishment or school.

A final important aspect of EU higher education is the European Research Area (ERA), for which the Lisbon Treaty introduced a legal basis in Article 179(1) TFEU. ${ }^{45}$ According to the text of Article $179 \mathrm{FEU}$, this area is characterized

41 Court of Justice, judgment of 13 November 2003, case C-153/o2, Valentina Neriv. European School of Economics.

42 Council Directive 93/96/EEC of 29 October 1993 on the right of residence for students, $O J$ $L_{317}, 18.12 .1993$.

43 Directive 2004/38/EC of the European Parliament and of the Council of 29 April 2004 on the right of citizens of the Union and their family members to move and reside freely within the territory of the Member States amending Regulation (EEC) No 1612/68 and repealing Directives 64/221/EEC, 68/36o/EEC, 72/194/EEC, 73/148/EEC, 75/34/EEC, 75/35/ EEC, 9o/364/EEC, 9o/365/EEC and 93/96/EEC, OJ L 158, 30.4.2004, p. 77-123.

44 Preamble (para. 14) of Directive (EU) 2016/801 of the European Parliament and of the Council of 11 May 2016 on the conditions of entry and residence of third-country nationals for the purposes of research, studies, training, voluntary service, pupil exchange schemes or educational projects and au pairing, OJ L 132, 21.5.2016, p. 21-57.

45 The European Research Area was initiated by the Commission in 2000, сом(2000) 6 final of 18.1.2000, and established by a Council Resolution of 15 June 2000 establishing a European Research Area. 
by increased mobility of researchers, scientific knowledge and technology, and increased "competitiveness" of the European research sector. This is to be achieved by collaboration among the various actors engaged in research, both private and public; through the use of the internal market freedoms; and through the definition of common standards, for which Article 182(5) TFEU provides a legal basis prescribing the ordinary legislative procedure. In 2010, the European Council indicated its intention to have "the European Research Area completed by 2014 to create a genuine single market for knowledge, research and innovation". ${ }^{46}$ That declaration also indicated mobility as a priority, noting that: "[i]n particular, efforts should be made to improve the mobility and career prospects of researchers, the mobility of graduate students and the attractiveness of Europe for foreign researchers". ${ }^{47}$ Researchers can, in principle, qualify as "workers" in the sense of Article 45 TFEU when they perform services under direction in return for remuneration, ${ }^{48}$ but when they carry out their activities on the basis of a grant rather than a traditional salary, these conditions may not be met. ${ }^{49}$ Several further obstacles tend to hamper mobility: many vacancies are not (internationally) openly accessible, many jobs in this sector still require (at least some degree of) knowledge of the national language; and social security provisions for researchers are highly heterogeneous and transferability of entitlements is troublesome.

Facing these challenges, the EU has adopted various policy measures. In 2005, the European Commission adopted a European Charter for Researchers and a Code of Conduct for the Recruitment of Researchers. ${ }^{50}$ For the purpose of open, transparent and merit-based recruitment, the EU created the EURAXESS Jobs Portal, ${ }^{51}$ the use of which is uneven but growing. ${ }^{52}$ In 2014, RESAVER was launched. This is a single European pension arrangement offering a defined contribution plan, tailor-made for research organisations and their employees, to enable mobile and non-mobile employees to remain affiliated to the same pension vehicle when moving countries and changing

$46 \quad$ EUCO 2/1/11 REV of 8 March 2010.

47 Ibid.

48 See Court of Justice, judgment of 17 July 2008, case C-94/o7, Andrea Raccanelliv MaxPlanck-Gesellschaft zur Förderung der Wissenschaften $\mathrm{eV}$.

49 Ibid.

50 Commission Recommendation of 11 March 2005 on the European Charter for Researchers and on a Code of Conduct for the Recruitment of Researchers, OJ L 75, 22.3.2005, p. 67-77.

$5^{1}$ http://ec.europa.eu/euraxess/.

52 About $47 \%$ of researcher job postings in 2014 with $7.8 \%$ compound annual growth rate in the period 2012-2014 in the EU. European Commission (2016). European Research Area Progress Report 2016, SWD (2017)21, available at: http://ec.europa.eu/research/era/pdf/ era_progress_report2016/era_progress_report_2016_swd.pdf. 
jobs. ${ }^{53}$ Furthermore, the European Research Council (ERC), which was established in its current form in $2007,{ }^{54}$ has had significant success in 'opening up' research activities to competition at European level. As von Bogdandy notes: " $t]$ he success rate in obtaining funding from one of its programs is perhaps the most visible instrument for an intra-European comparison regarding the attractiveness and capability of the research institutions of the member states".55 Indeed, for many the most tangible element of the ERA is the funding for research it provides under Horizon 2020, which amounts to 8 billion EURO.

The ERA and EHEA have very different legal statuses from an EU law perspective. The ERA is firmly based in the Treaties and the EU's institutional setting, while as mentioned the EHEA is a feature of "public international soft law". ${ }^{66}$ Still, there is a "substantial degree of resemblance in terms of scope, governance and working methods, actors and activity types". ${ }^{57}$ There is also a certain alignment in overall political orientation, as both aim to increase competition and introduce market mechanisms in the higher education sector ${ }^{58}$ The fact that such sensitive decisions are taken through soft law processes, implying a certain accountability deficit, has met with some criticism. ${ }^{59}$

\section{The UK and European Higher Education Law and Policy}

\section{1}

The UK and the Bologna Process

Whereas at the end of the last century, other European countries were struggling with the faltering influence and standing of their once so glorious

53 See European Commission (2014). New pan-European pension fund to boost researcher mobility, available at http://europa.eu/rapid/press-release_IP-14-1063_en.htm and http:// www.resaver.eu.

54 Commission Decision of 17 February 2015 amending Decision C(2013) 8915 establishing the European Research Council, OJ C 58 , 18.2.2015, p. 3-5.

55 Von Bogdandy, A. (2012). National legal scholarship in the European Legal Area A Manifesto. International Journal of Constitutional Law 10 (3), pp. 614-626.

56 Hackl, E. (2001). Towards a European Area of Higher Education, cit, p. 28.

57 Van der Hijden, P. (2012). Mobility Key to the EHEA and ERA. In: Curaj et al, eds., European Higher Education at the Crossroads: Between the Bologna Process and National Reforms. Dordrecht: Springer, p. 378.

$5^{8}$ See Garben, S. (2010). The Bologna Process and the Lisbon Strategy: Commercialisation of Higher Education through the Back Door?. Croatian Yearbook of European Law and Policy 6 (6), pp. 209-23o.

59 Ibid. See also Gideon, A. (2015). The Position of Higher Education Institutions in a Changing European Context: An EU Law Perspective. Journal of Common Market Studies 53 (5), pp. 1045-1060. 
universities, and accordingly with the decreasing attractiveness of their higher education systems, ${ }^{60}$ the only problem the UK had in attracting foreign students was that there were too many applicants from all over the world eager to study at the UK's universities, because of their world-class reputation and because of the opportunity for students to develop their English-language skills. ${ }^{61}$ Accordingly, "the UK's strong position in European higher education raises questions about why it needs to be involved in the Bologna Process, what it has to gain, and why the UK should help other countries in the EHEA to modernise if that is going to risk its competitive advantage". ${ }^{2}$ For indeed, the model towards which convergence was directed in the Sorbonne and Bologna Declarations closely resembles the UK Bachelor-Master system, which could have meant that other countries would copy precisely the aspects of the UK's higher-education system that are considered to be responsible for its success. That would risk diminishing the UK's advantageous position, without any additional benefits for the UK itself. Why indeed then, one could ask, is the UK one of the four founding members of the Bologna Process?

The initiative for the Bologna Declaration surely came from the French, Italian and German ministers more than from its fourth signatory, the UK junior minister Baroness Tessa Blackstone. The other three ministers already knew each other and had been discussing some of the issues already well before the Sorbonne event. ${ }^{63}$ Hoareau reports that only "once France, Germany and Italy had agreed on the principle of a reform of degrees establishing an undergraduate degree of three years, and two postgraduate levels in two and eight years" they "contacted the British minister". ${ }^{64}$ The three initiators were well aware that for the Declaration to have an optimum impact they needed the

6o See for extensive discussion Garben, S. (2014). EU Higher Education Law, cit.

61 Furlong, P. (2005). British Higher Education and the Bologna Process: An Interim Assessment. Politics 25 (1), pp. 53-61.

62 House of Commons, Education and Skills Committee (2007). The Bologna Process, Fourth Report of Session $2006-7,6$.

63 The three ministers from France, Germany and Italy had "come to know and esteem one another in the context of a virtually unknown international organization, sometimes called the "G8 of research", the largely informal grouping of the ministers for research in the key industrialized countries of the world established by the Carnegie Commission on Science, Technology and Government". Tessa Blackstone, as a junior minister, was not in charge of research and had therefore not been a part of these conferences. Schriewer, J. (2009). Rationalized Myths in European Higher Education: The Construction and Diffusion of the Bologna Model. European Education 41 (2), pp. 31-51.

64 Hoareau, C. (2009). Consequential Deliberative Governance? Analysing the Impact of Deliberation on Attitudinal and Policy Change in the European Higher Education Area. London School of Economics Working Paper. 
UK onboard "in light of the political clout the UK has as one of the "larger" EU Member States". ${ }^{65}$ Blackstone agreed to participate, probably because of the idea that the Bologna Process only proposed convergence towards the UK model. Indeed, Blackstone stated that signing the Sorbonne Declaration "was a riskier action"66 for the other three signatories than for her: "They were committing their own systems of higher education to much greater change than I. The Anglo-Saxon model that was proposed that day in May 1998 was essentially the one that prevailed in the United Kingdom as well as North America. We in Britain had to make relatively few adaptations. In France, Germany and Italy more change was required following the Declaration". ${ }^{67}$

Together with this idea that no reforms would be required, it was important for Blackstone that the project would be a strictly intergovernmental one, without any binding agreement, and for that reason she was keen to keep the EU and the European Commission out.

It is reported that when Blackstone returned from the Sorbonne meeting, she did face some "criticism for signing something so "European" as a declaration on a common European Higher Education Area".68 But contrary to what one might expect, it seems that there was no real controversy or even a heated public debate about the UK's participation in (creating) the EHEA. Blackstone's justification for her signature, stressing that the agreement only implied that Britain's system would be introduced elsewhere, ${ }^{69}$ was apparently convincing enough. The government, the higher education sector and the public were all more or less on the same side, because the UK government did not have an agenda to participate in the Bologna Process to push national reforms in the same sense many of the governments of the other participating countries had. ${ }^{70}$ In contrast to the governmental rhetoric in those other countries, UK officials were eager to water down the importance of the Declaration, stressing that no reforms would be necessary as the UK was the model country anyway. Indeed, its higher education sector was not subjected to the massive and sometimes painful reorganizations that their colleagues on mainland Europe

65 Schriewer, J. (2009). Rationalized Myths in European Higher Education: The Construction and Diffusion of the Bologna Model, cit, p. 37.

66 Blackstone T., Education and Training in the Europe of Knowledge, link no longer available.

67 Ibid.

68 Martens, K. and Wolf, K. (2009) Boomerangs and Trojan Horses: The Unintended Consequences of Internationalizing Education Policy through in the EU and the OECD. In: Amaral et al, eds., European Integration and the Governance of Higher Education and Research. Dordrecht: Springer, p. 81et seq.

69 Ibid.

70 For extensive discussion, see Garben, S. (2014). EU Higher Education Law, cit. 
faced in the wake of Bologna. This might have contributed to the fact the UK reaction mainly consisted of "complacency, based on the view that much of this amounts to catch-up by other European countries"71 combined with a sort of indifference to Bologna's ins and outs.

This is not to say that the UK was not actively involved in the Process from the beginning. Seminars and meetings were organized on a relatively frequent basis already a few years after the signing of the Declarations. The national Quality Assurance Agency launched a national framework for higher education qualifications "with careful descriptions of bachelors and master's degree qualifications" in 2000. ${ }^{72}$ In 2003, the UK Government ratified the Lisbon Recognition Convention, a key Bologna aim. A survey of UK higher education institutions by the Europe Unit in 2005 indicated considerable awareness and engagement with the Bologna Process among those institutions. However, it can be said that it was only in 2006, when the House of Commons Education and Skills Committee launched an inquiry focusing on Bologna that any kind of substantive debate really materialized. The inquiry was undertaken in the immediate run-up to the Bologna Process' London Ministerial Summit of May 2007 "in order to facilitate broad discussion of the UK position" "with the intention of making a constructive contribution to the negotiations at the 2007 Summit and beyond". ${ }^{73}$ The Report thoroughly addressed the question why the UK should participate, because "as a European leader in higher education, the benefits of engagement in the Bologna Process might not be as immediately obvious for the UK as they are for other signatory countries in the E HEA".74 As a minimum case for membership, it was argued that in the rapidly developing global market for higher education, the UK could simply not afford not to be involved. "The modernization of European higher education would continue to take place regardless of UK involvement and could have implications for the recognition of UK courses and competitive position".75 It would therefore be better to participate and attempt to influence and steer the Process from the inside. ${ }^{76}$ The Report made it clear that a sense of complacency had to be

71 Furlong, P. (2005). British Higher Education and the Bologna Process: An Interim Assessment, cit, p. 6 o.

72 Cowen, R. (2008). The Bologna Process and Higher Education in England. In: Palomba, ed., Changing Universities in Europe and the 'Bologna Process'. Comparative Education Studies, p. 58 .

73 House of Commons Education and Skills Committee (2007). The Bologna Process cit, p. 3.

74 Ibid, p. 25.

75 Ibid.

76 In the words of a UK Minister: "The problem is that they [mainland Europe] will get on with it, they will continue with this process and, given the competitive pressures that 
avoided, and identified the pressure that the convergence process put on the UK's higher education system. The competitive advantage in attracting overseas students, traditionally a particular focus of the UK, could be reduced if "comparability and compatibility would develop apace across the EHEA without efforts from the UK to keep up".

Beyond the minimum case for membership, the Report identified some significant benefits for the UK in active Bologna participation. The Committee found government and the organizations representing higher education to agree about such advantages, supported by student organizations as well as university leaders and academic staff involved in implementing the Bologna principles and action lines in practice. Engagement in the Process could be economically beneficial, through increased employment and productivity. Furthermore, involvement could increase the competitiveness of the UK higher education sector through promoting the attractiveness and international reputation of the EHEA at large. In addition, the Report pointed out that UK students could profit from increased mobility and employment opportunities. With regard to UK universities, active Bologna membership could guarantee an increased market for both EU and international students within the EHEA, increased mobility of staff, sharing of best practice and expertise in a broad range of areas, and increased opportunities for research collaboration across the ERA. All these considerations led the Committee to conclude that there were not only significant dangers for the UK not to be actively involved in the Bologna Process, but that there were also some significant advantages to be gained from membership, with the Bologna action lines increasingly reflecting the policy priorities in the UK. This settled the question of the desirability of the UK's membership of the Bologna Process, almost ten years after it had helped create it.

\section{2}

The UK and EU Higher Education and Policy

In EU higher education law and policy, the UK equally occupies a privileged position. First and foremost, the UK and its higher education sector has been one of the main beneficiaries of the ERA. UK higher education institutions are highly successful in acquiring EU research funding, with the highest number

exist, over time for some of our institutions, I think that could hit them competitively in that they have ended up in a situation where a system of comparability and compatibility is developed elsewhere in the broader Europe [and] we are not a part of it [...] that is why I think the process is happening, we need to embrace it and we need to influence it in our national interest". See House of Commons Education and Skills Committee (2007). The Bologna Process, cit, p. 25. 
of Horizon 2020 submissions obtaining the $2^{\text {nd }}$ highest share of all funding, amounting to $15.2 \%$ of overall available funding (as well as benefitting indirectly from funding allocated to their project partners from elsewhere in the EU). ${ }^{77}$ It has been estimated that EU research funding generates more than 19,000 jobs across the UK, £1.86 billion for the UK economy and contributes more than $£_{1}$ billion to GDP, according to a report produced for Universities UK. ${ }^{78}$

As regards student mobility, as set out in Part II.B above, EU law requires equal treatment in higher education as regards all access conditions, including tuition fees, but allows a 5 -year prior residence requirement to be applied for the purposes of maintenance support. While it is difficult to establish an accurate overall financial picture, it can be expected that EU law as it currently stands thus plays out to the benefit of the UK system, which charges high tuition fees to all students (up to $£ 9,25 \circ$ ) ${ }^{79}$ and provides its main subsidies to individual students through maintenance grants and loans. Of course, EU law prevents the UK from charging higher tuition fees to foreign EU students than it charges national students and, considering the UK's status as the biggest netimporter of students in the EU, this implies an opportunity cost. On the other hand, if the UK were in fact to charge higher tuition fees, it could be projected that fewer EU students would come. In any event, compared to Member States that do not charge any, or only low, tuition, the UK is required to pay less in regard to foreign students. Furthermore, UK students can, of course, benefit from other Member States' more 'generous' education systems.

It may even be that the UK has a net financial benefit per foreign EU student. EU students will only be entitled to undergraduate tuition fee loans, to cover their $\pm £ 900$ yearly fees, which will have to be repaid. Only if they become permanent residents after 5 years of legal stay in the UK, can they apply for undergraduate maintenance support. ${ }^{80}$ As the loan is on 'friendly conditions' and not all is always paid back, this of course can still be estimated to come at

77 European Commission (2018). Horizon 2020 in Full Swing, Key Facts and Figures 2014 - 2016. Luxembourg : Publications Office of the European Union available at https://ec.europa. eu/programmes/horizon2020/sites/horizon2020/files/h202O_threeyearson_a4_horizontal_2018_web.pdf.

78 Kelly, U. (2016). Economic Impact on the UK of EU Research Funding to UK Universities, available at: https://www.universitiesuk.ac.uk/policy-and-analysis/reports/Documents/ 2016/economic-impact-of-eu-research-funding-in-uk-universities.pdf.

79 The cost of studying at a university in the UK (2017). Times Higher Education, December 1, available at: https://www.timeshighereducation.com/student/advice/coststudying-university-uk.

8o Students with 3 years prior residence, but not for the main purpose of receiving full-time education during any part of this 3-year period, also have access to maintenance loans. 
some cost to the UK taxpayer. ${ }^{81}$ However, the EU student also spends money in the UK on various living costs such as accommodation, food and general consumption, meaning that on balance this could be projected to break even for the UK economy as a whole. As to the financial position of the universities themselves, while some are claiming that a student costs a university £16.ooo a year, ${ }^{82}$ there is no transparency concerning the calculations on which these figures are based. ${ }^{83}$ It is possible that in the average cost of a student to the institution, universities calculate their various bursary and scholarship schemes which may in fact not always be accessible to EU students. This means that EU students may in certain cases be financing UK students at UK universities. In any event, all these calculations are of course apart from the less calculable but highly valuable knowledge the EU students bring to UK classrooms, the internationalization that adds to the overall competitiveness of the sector and other more intangible benefits to the UK economy and society at large.

If it is indeed considered that importing EU students provides the UK and its universities with significant benefits, it must thank the Court of Justice for its interpretation of EU law that made studying abroad so attractive even before the Bologna Process. Beyond access conditions and fees, it is the 'outcome' of studying that is of major interest to students. The leading case of $\mathrm{Kraus}^{84}$ illustrates this well. The German student Dieter Kraus studied law in Germany and passed the first State examination in law in 1986. In 1988 he obtained the university degree of Master of Laws (LL.M) following postgraduate study at the University of Edinburgh in the UK. In 1989 Mr Kraus sent a copy of his LL.M degree certificate from the University of Edinburgh to the Ministry of Sciences and Arts of the Land Baden-Wuerttemberg, requesting confirmation that, having done so, there was nothing further to prevent him from using his title in the Federal Republic of Germany. The Ministry replied that his request could be allowed only if he made a formal application for the authorization prescribed

81 For the highly complex calculations that could be made in this regard, see: Institute for Fiscal Studies (2014). Estimating the Public Cost of Student Loans, available at: https:// www.ifs.org.uk/comms/rg4.pdf.

82 Garner, O. (2013). We Need Tuition Fees of Up to £16,ooo, Says Oxford Vice-Chancellor Professor Andrew Hamilton. The Independent, October 9, available at: https://www.independent.co.uk/student/news/we-need-tuition-fees-of-up-to-16ooo-says-oxford-vicechancellor-professor-andrew-hamilton-8867323.html.

83 Oxford Teaching and the £16K Question - How Does the University Calculate the Real Cost of Undergraduate Education? Times Higher Education, available at: https://www. timeshighereducation.com/news/oxford-teaching-and-the-16k-question/2008179.article.

84 Court of Justice, judgment of 31 March 1993, case C-19/92, Dieter Kraus v. Land Baden Württemberg. 
for the purpose by German law, using the appropriate form and attaching to it a certified copy of the diploma in question. Mr Kraus subsequently sent a certified copy of his Edinburgh degree, but refused to submit a formal application for authorization on the ground that the requirement for such an authorization prior to the use of an academic title awarded in another Member State constituted an obstacle to the free movement of persons and also discrimination, both prohibited by EU law, since no such authorization was required for the use of a diploma awarded by a German establishment.

The Court of Justice considered that the freedom of movement for workers and freedom of establishment were hampered by a lack of academic diploma recognition, since the possession of an academic title constitutes "an advantage for the purpose both of gaining entry to such a profession and of prospering in it", improving "its holder's chances of appointment" and may lead to "higher remuneration or more rapid advancement or [...] access to certain specific posts reserved to persons with particularly high qualifications", and since "the possibility of using academic titles awarded abroad and supplementing national diplomas required for access to a profession greatly facilitates establishment as an independent practitioner and, in any event, the pursuit of a corresponding professional activity". ${ }^{85}$ While Member States are allowed to restrict these freedoms in the interest of preventing abuse of academic titles, any authorization procedure must be intended solely to verify whether the postgraduate academic title obtained in another Member State was properly awarded, following a course of studies which was actually completed, in an establishment of higher education which was competent to award it. ${ }^{86}$ The procedure must be easy of access and should not be excessively expensive. ${ }^{87}$ Any refusal of authorization must be capable of being subject to judicial proceedings in which its legality under EU law can be reviewed and that the person concerned must be able to ascertain the reasons for the decision taken with respect to him. ${ }^{88}$ Finally, whilst the national authorities are entitled to prescribe penalties for non-compliance with the authorization procedure, the penalties imposed should not exceed what appears proportionate to the offence committed. ${ }^{89}$ As this provides important guarantees to any mobile student, this case law can be considered as instrumental to student mobility as the well-known Gravier doctrine.

85 Paragraphs $18-23$ of the judgment.

86 Paragraph 38 of the judgment.

$87 \quad$ Paragraph 39 of the judgment.

88 Paragraph 40 of the judgment.

89 Paragraph 41 of the judgment. 
Another leading diploma recognition case similarly shows how UK higher education institutions benefit from EU mobility rights, in an even more direct sense. Universities themselves can rely on the freedom to provide services and the freedom of establishment to offer for-profit education in other EU Member States. This reportedly comprises $13 \%$ of the UK higher education's sector's "transnational education" activities, which are an important profit-yielding part of its higher education model. ${ }^{90} \mathrm{Ms} \mathrm{Neri}{ }^{91}$ enrolled at Nottingham Trent University ("NTU") with a view to acquiring a BA Honours degree in International Political Studies on completion of a four-year course of studies. Nottingham Trent University is a university subject to UK legislation included in the list of bodies authorised to award BA honours degrees having legal status. While Nottingham Trent University generally administers its courses of study at its establishment in the UK, where final degrees are awarded, it also provides for an 'outsourced' system in accordance with Article 216 of the Education Reform Act 1988. Under Article 216 of the Education Reform Act, the Secretary of State approves a list of bodies who may provide any course which is in preparation for a degree to be granted by a recognised body and is approved by or on behalf of the recognised body, which includes the European School of Economics (ESE). The ESE is thus a Higher Education College authorised according to the UK educational system to organise and provide the university courses of study approved by NTU. It is incorporated as a limited liability company, established in the UK with a number of secondary establishments in other Member States, having 12 branches in Italy. ESE does not award its own degrees but for remuneration organises courses for the students enrolled with NTU in accordance with study plans validated by that university, which then awards a final degree of Bachelor of Arts with Honours. The quality of the courses of study provided by ESE is also subject to audit by the UK Quality Assurance Agency for Higher Education.

In view of the high financial cost attendant on residence in the UK for the entire duration of her studies, Ms Neri decided to attend university courses in Italy at ESE. Having enrolled for the first year of the course of studies held by ESE in Genoa, she learned from authoritative Italian sources that ESE was not authorised to organise university-level courses and that recognition could not be granted to the university's degrees, albeit legally recognised in the United

$90 \quad$ Boe, L., The Scale of UK Higher Education Transnational Education 2015-16. Universities UKInternational available at: https://www.universitiesuk.ac.uk/International/Documents/ The\%2oScale\%20of\%2oUK\%2oHE\%2oTNE\%2O2O15-16.pdf.

91 Court of Justice, judgment of 13 November 2003, case C-153/o2, Valentina Neriv. European School of Economics. 
Kingdom, if they had been obtained on the basis of periods of study completed in Italy. On this basis, Ms. Neri brought a case that was referred to the Court of Justice. The Court considered that the organisation for remuneration of university courses is an economic activity falling within the chapter of the Treaty dealing with the right of establishment and that "for an institution like ESE, which organises courses intended to enable its students to obtain degrees capable of facilitating their access to the employment market, the recognition of those degrees by the authorities of a Member State is of considerable importance". ${ }^{92}$ The Court held that it was clear that the Italian administrative practice, under which certain degrees awarded at the end of a university training course given by ESE are not recognised in Italy, is likely to deter students from attending these courses and thus seriously hinder the pursuit by ESE of its economic activity in that Member State. The Italian Government considered that restriction justified by the need to ensure high standards of university education. It maintained that the Italian legal order did not accept agreements such as the one between ESE and Nottingham Trent University since it remains attached to a view of such education as a matter of public interest, expressing as it does the cultural and historical values of the State. According to the Italian Government, such an agreement on university education prevents direct quality control of these private bodies by the competent authorities both in the Member State of origin and the host Member State. The Court however held that "given that the Italian legal order appears to allow, pursuant to Article 8(1) of Law No 341/9o, agreements between Italian universities and other Italian establishments of higher education which are comparable to the agreement entered into between NTU and ESE" and since the non-recognition of degrees in question appeared to relate solely to degrees awarded to Italian nationals, the administrative practice did not appear suitable for attaining the objective of ensuring high standards of university education. Furthermore, the administrative practice was disproportionate, since it appeared "to preclude any examination by the national authorities and, consequently, any possibility of recognition of degrees awarded in circumstances like those in the main proceedings". ${ }^{93}$ Thus, the upshot of the judgment is that while Member States may under circumstances limit the activities of for-profit higher education institutions on their territory, this is by way of exception to the internal market freedoms and therefore will have to comply with high standards of proportionality. As the facts of this case also clearly show, these provisions of EU law, as

92 Paragraph 42 of the judgment.
93 Paragraph 49 of the judgment. 
interpreted by the Court, are of particular benefit to the UK higher education system and its institutions.

\section{The Implications of, and on, Brexit}

The exact implications of 'Brexit', are of course difficult to predict, especially as everything hinges on the specific conditions of the (various?) agreement(s) that the UK and the EU may conclude, if any, as well as complex and volatile political dynamics. Even in the case of a 'hard Brexit', the future may see subject-specific cooperation agreements, which could very well include the area of higher education, where non-EU Member States regularly participate in various EU policies. ${ }^{94}$ Then again, even the 'softest' of Brexits may have profound implications for UK and European higher education, particularly if it were to in any way dilute mobility rights or re-organize research funding. These considerations thus limit the predictive effect of anything we may project or conclude in this chapter. It can nevertheless be insightful, and hopefully somehow useful, to reflect on how the underlying dynamics in the area of higher education, as explored in the previous parts of this chapter may be affected by - and themselves affect - the UK's secession from the Union. The previous analysis has exposed a number of relevant 'stakes' and 'pressure points' when it comes to European higher education and the UK's position in it, which are likely to come to the fore in the Brexit negotiations and afterwards, in postBrexit Europe, in respect of the area of higher education.

As regards the EHEA, it can firstly be presumed that the UK will remain party to it post-Brexit, as participation to the Bologna Process is entirely independent from EU membership. The Process is voluntary, so there is no reason to fear any loss of sovereignty, and in its post-Brexit isolation, this may par excellence be one of the remaining forums within which the UK can still seek to 'lean in' on international affairs. In this respect, it is interesting to recall the comments made by a UK Minister in relation to UK participation in Bologna:

The problem is that they [mainland Europe] will get on with it, they will continue with this process and, given the competitive pressures that exist, over time for some of our institutions, I think that could hit them competitively in that they have ended up in a situation where a system of comparability and compatibility is developed elsewhere in the broader 
Europe [and] we are not a part of it [...] that is why I think the process is happening, we need to embrace it and we need to influence it in our national interest. ${ }^{95}$

These remarks have some additional poignancy, as they can be read to be about EU membership in general as much as about Bologna participation. They clearly show the stakes on the side of the UK: how to maintain influence international decision-making and the capacity to pursue the national interest, especially considering economic competitive forces, while being excluded from the most important decision-making forum?

As such, it would not be wholly unexpected for the UK to seek to actually increase the standing and broaden the material scope of the Bologna Process, possibly 'pulling' as much as it can away from the EU in this area, thereby hoping to represent its interests (particularly the interest of its higher education sector, and the public purse) and achieve its policy objectives concerning student mobility, diploma recognition and perhaps even research funding somehow within this purely intergovernmental project in which it can be expected to remain a full and influential member. Such would be a strategic course of action for the UK, considering that as we have seen in the previous sections, much of the Bologna Process depends, in reality, on EU law to give actual effect to it. It is EU law that grants hard and enforceable rights to individual students, teachers and higher education institutions, that make the (proclaimed virtues of the) EHEA from a paper tiger into a tangible reality. It would thus be rational for the UK to try and pry as much of that away from the EU as possible, or in any event to try and reach comparable outcomes in the context of Bologna. Clearly, it remains to be seen whether it will have any success in this regard. As was reported in Part II.1. above, the UK was able to exclude the EU from Bologna, particularly as it found support in this from a number of other (larger) EU Member States. On the other hand, smaller Member States were less keen on this intergovernmentalism, as it exposes them to the more traditional international power-play against which the EU is, in many ways, a bulwark. ${ }^{96}$ Especially these countries are not likely to agree to (further) exchange the EU-forum for education law and policy making for the Bologna one. And in the post-Brexit climate, other larger EU Member States may be much less favourable towards the UK, its economic

95 See House of Commons Education and Skills Committee (2007). The Bologna Process, cit, p. 25 .

For extensive discussion, see: Garben, S. (2014). EU Higher Education Law, cit. 
interests, and thus any of its attempts to assert Bologna over the EU decisionmaking process.

Whether there will be any such overt clashes of course remains to be seen. Overall, it should be emphasized that the policy-discourse of Bologna and of EU higher education policy have been very much in line. Both have been championing an Anglo-Saxon 'liberal' model of higher education, in which education is conceptualized mainly in economic terms, as self-investment and market-driven, as opposed to the social model of higher education that sees it as a social entitlement for all citizens and a responsibility of the state. ${ }^{97}$ Within the former model, one would tend to see more involvement of private and for-profit actors, deregulation, the establishment of quasi-markets and of public-private partnerships, and more generally an instrumental, labour market approach to higher education. The latter model instead tends to make state involvement central, will be focused on widening access to higher education, and may emphasize the citizenship-role of education and the pursuit of knowledge for knowledge's sake. Within the Bologna Process, the preference for the former, 'liberal' model can be seen in its emphasis on 'employability' of graduates, which is operationalized through its requirement that the BA degree has 'labour market value' (whereas before, in most continental European countries, an MA equivalent was usually needed for such labour market recognition), and, even more importantly in practice, through its quality assurance processes. In national accreditation procedures, which higher education institutions often need to follow to be authorized to award degrees under national (but often Bologna-inspired) law, the Bologna-'requirements' on 'employability' are given real teeth, and it is here that much of the influential 'steer' happens: universities are forced to show how their programmes (aim to) guarantee certain economic, labour market-outcomes, for otherwise they may jeopardize their very existence.

Within an EU context, analysis in Part III.2. has shown how EU law tends to play out to the favour of a liberal model such as the UK's, and that it puts a higher burden on more social models that tend to subsidize higher education through open and free (or low-tuition) access. Furthermore, in recent years one of the most important sources of EU involvement in higher education is through its yearly cycle of economic policy coordination: the European Semester, where education is explicitly considered as a factor of economic stability and growth. The Country Specific Recommendations (CSRs) are predominantly concerned with the 'cost-effectiveness' and 'employability' of Member 
States' education systems. For instance, Denmark has been told that "[c]ontinued efforts are $[\ldots]$ needed to improve the quality and cost-effectiveness of its education and training systems", ${ }^{8}$ Estonia to "[1]ink training and education more effectively to the needs of the labour market" ${ }^{\prime \prime 9}$ and Malta that it should "focus education outcomes more on labour market needs". ${ }^{100}$ The CSR s can be remarkably detailed and specific on the required reforms concerning various aspects of national education systems. ${ }^{101}$ For example, the Commission's proposed CSR s in 2017 for Croatia states: "Since 2015, as part of the implementation of the education, science and technology strategy, a reform of the school curricula was launched to improve on content and teaching of transferable skills. After ambivalent stakeholder reactions, the curricular reform was revised, and implementation has been significantly delayed. The process now needs to continue in line with the original objectives". ${ }^{102}$ Furthermore, the CSR s reflect a clear policy to increase the involvement of the private sector in higher education and to make the funding of higher education 'competitive'. In this vein, for instance, Bulgaria has been given the recommendation that "frameworks fostering collaboration between universities and the private sector have to be further developed, and funding should be allocated in a competitive, merit-based and transparent way", and to "pursue the reform of higher education, in particular through better aligning outcomes to labour market needs and strengthening cooperation between education, research and business",103

98 Council Recommendation of 9 July 2013 on the National Reform Programme 2013 of Denmark and delivering a Council opinion on the Convergence Programme of Denmark, 2013-2016, OJ C 217, 30.7.2013, p. 18-20, para. 12.

99 Council Recommendation of 10 July 2012 on the National Reform Programme 2012 of Estonia and delivering a Council Opinion on the Stability Programme of Estonia, 2012-15, OJ C 219, 24.7.2012, 25 - 27, para. 14.

100 Council Recommendation of 12 July 2011 on the National Reform Programme 2011 of Malta and delivering a Council opinion on the updated Stability Programme of Malta 2011-2014, OJ C 215, 21.7.2011, p. 10-12, point 3.

101 This could be said to sit uncomfortably with the national autonomy clause in Article 165(1) TFEU that EU action should fully respect the responsibility of the Member States for the content of teaching and the organisation of education systems.

102 European Commission, Recommendation for a Council Recommendation on the 2017 National Reform Programme of Croatia and delivering a Council opinion on the 2017 Convergence Programme of Croatia, COM/2017/0510 final.

103 Council Recommendation of 10 July 2012 on the National Reform Programme 2012 of Bulgaria and delivering a Council opinion on the Convergence Programme of Bulgaria,2012-15, para. 16, OJ C 219, 24.7.2012, 9 - 12, and Council Recommendation of 9 July 2013 on the National Reform Programme 2013 of Bulgaria and delivering a Council opinion on the Convergence Programme of Bulgaria, 2012-2016, OJ C 217, 30.7.2013, p. 1013, point 4 . 
Estonia to "enhance cooperation between businesses and academia",104 and Italy to address the "underperformance of the tertiary education system" inter alia by creating "a stronger link between universities' performance and the allocation of public funding". 105

All this means that the general direction of the discourse in the Europeanisation of higher education, both in the context of the Bologna Process and the EU, is very much in line with the UK's approach, and benefits its model of higher education and its economic stakes in that model. Brexit is unlikely, as such, to bring any fundamental changes in this regard. ${ }^{106}$ The extent to which the UK will be able to continue to directly benefit from this development of continental higher education into a market-model like its own, is however likely to change fundamentally with Brexit. As the analysis in Part III.2. showed, UK higher education institutions rely heavily on EU law to be able to offer services in other Member States and to be able to import talented students (the financial picture of which is unclear but which may, under the high tuition fee system, bring direct economic benefits to the universities as well as many indirect beneficial effects), and - through EU research grants - for the overall funding of its higher education and research and development sector(s). In this regard, the UK stands to lose more from Brexit than the other EU Member States: EU students, teachers, researchers and higher education institutions will still have access to 27 higher education systems, and they can continue to create a fully effective internal higher education and research area, as well as an internal market for higher education. In fact, now that following the UK's

104 Council Recommendation of 10 July 2012 on the National Reform Programme 2012 of Estonia and delivering a Council Opinion on the Stability Programme of Estonia, 2012-15, cit., para. 14 .

105 Council Recommendation of 10 July 2012 on the National Reform Programme 2012 of Italy and delivering a Council opinion on the Stability Programme of Italy, 2012-2015, OJ C 219, 24.7.2012, 46 - 49, para. 16 .

106 It has, however, been noted that in the context of allocation of European research funding, there have been "tensions between countries favouring competitive research funding and countries preferring a less competitive and more egalitarian system". Alongside the Netherlands and Denmark, the UK has been the most important supporter of the competitive model. Without the UK at the table, this may change, which is a matter of concern for some stakeholders in the Netherlands and Denmark. See Courtois, A. (2018). Reconfiguring the European higher education sector. University World News June 22, available at https://www.universityworldnews.com/post.php?story=20180621101812552 and the full report Courtois A., ed. (2018). Higher education and Brexit: current European perspectives. Centre for Global Higher Education, available at: https://www.researchcghe.org/publications/special-report/higher-education-and-brexit-current-europeanperspectives/. 
lead, EU Member States' higher education systems have become each other's competitors, there is much to gain from the UK's weakening role, and some other Member States are indeed gearing up to take over from the UK as 'EU leader in Higher Education'. Higher education may turn into one of Brexit's major spoils.

These projected consequences of Brexit of course may influence the Brexitprocess and negotiations themselves. EU higher education law and policy, with all its current benefits for the UK, is thus an important bargaining chip for the EU, both within the negotiations and potentially as leverage for the UK's compliance with its obligations under any future relationship. As such, the UK's current strength in higher education is one of its weak spots in the Brexit negotiations. The two key issues in this regard are on the one hand research funding under Horizon 2020, of which the UK is one of the main beneficiaries, and on the other hand the internal market freedoms and mobility rights connected to EU citizenship that foster the economic activities of the UK higher education sector. While the former could arguably be negotiated between the EU and the UK on an ad hoc basis, the latter is entirely dependent on the position of the UK in the internal market and will have to be part of any 'big' agreement on the future relationship between the EU and the UK. The UK may seek to use the Bologna Process as a 'back door' to pursue its key interests in this regard, but the potential effectiveness thereof is doubtful. It does, however, seem to be its most rational course of action, as it will need to seek alternative forums to 'win friends and influence people' once it has excluded itself from the most important forum to do so.

\section{Conclusion}

The UK higher education sector is estimated to generate $£ 95$ billion for the UK economy each year. It is difficult to calculate the precise direct and indirect negative impact on that lucrative sector in case Brexit would mean that the UK would have to give up EU research funding, student/staff (and knockon) mobility as well as UK transnational education, but it is likely to be significant. While the overall policy-direction of European higher education is likely to continue, also post-Brexit, to champion the marketization of higher education along the lines of the Anglo-Saxon, liberal model, ironically it can be expected that the UK as a non-member of that growing internal market of higher education and research will be able to benefit less and less from it. At the risk of oversimplification, it could be said that the UK has first been instrumental and influential in creating a lucrative continental market for higher 
education, and now it has excluded itself from that market, as well as from its position of influence. While, of course, also EU citizens are disadvantaged by a limitation of their mobility rights vis-à-vis the UK, they are in a better position to shift the focus to any of the other 27 Member States, who remain stronger together. 